\title{
Article \\ Synthesis, Crystal Structure and Optical Properties of 2-(3-(Hexyloxy)-5-Methylphenoxy)-N-(4-Nitrophenyl)acetamide for Anion Detection
}

\author{
Piangkwan Jansukra ${ }^{1}$, Tanwawan Duangthongyou ${ }^{1}$, Songwut Suramitr ${ }^{2}$, Kittipong Chainok $^{3}$ (D) \\ and Boontana Wannalerse ${ }^{1, *}$
}

1 Department of Chemistry and Center of Excellence for Innovation in Chemistry, Faculty of Science, Kasetsart University, Chatuchak, Bangkok 10900, Thailand; paengkwan.j@gmail.com (P.J.); fscitwd@ku.ac.th (T.D.)

2 Department of Chemistry, Faculty of Science, Kasetsart University, Bangkok 10900, Thailand; fsciswsm@ku.ac.th

3 Materials and Textile Technology, Faculty of Science and Technology, Thammasat University, Pathum Thani 12120, Thailand; kc@tu.ac.th

* Correspondence: fscibnw@ku.ac.th; Tel.: +66-25625555 (ext. 647582); Fax: +66-25793955

check for

updates

Citation: Jansukra, P.;

Duangthongyou, T.; Suramitr, S.;

Chainok, K.; Wannalerse, B. Synthesis,

Crystal Structure and Optical

Properties of 2-(3-(Hexyloxy)-5-

Methylphenoxy)-N-(4-Nitrophenyl)

acetamide for Anion Detection.

Crystals 2021, 11, 671. https://

doi.org/10.3390/cryst11060671

Academic Editor: Maija Nissinen

Received: 5 May 2021

Accepted: 7 June 2021

Published: 10 June 2021

Publisher's Note: MDPI stays neutral with regard to jurisdictional claims in published maps and institutional affiliations.

Copyright: (c) 2021 by the authors. Licensee MDPI, Basel, Switzerland. This article is an open access article distributed under the terms and conditions of the Creative Commons Attribution (CC BY) license (https:/ / creativecommons.org/licenses/by/ $4.0 /)$.

\begin{abstract}
In this study, 2-(3-(hexyloxy)-5-methylphenoxy)-N-(4-nitrophenyl)acetamide (sensor L1) was synthesized and characterized by FT-IR, ESI-MS, ${ }^{1} \mathrm{H}$ and ${ }^{13} \mathrm{C}$ NMR spectroscopy, elemental analysis, and single crystal X-ray techniques. The crystal structure and space group of sensor L1 was monoclinic and $P 21$, respectively. The crystal packing of sensor L1 was dominantly linked by two strong hydrogen bonds forming a six membered ring pattern. The binding properties of sensor $\mathrm{L} 1$ and various anions $\left(\mathrm{F}^{-}, \mathrm{Cl}^{-}, \mathrm{Br}^{-}, \mathrm{CH}_{3} \mathrm{COO}^{-}, \mathrm{C}_{6} \mathrm{H}_{5} \mathrm{COO}^{-}\right.$, and $\left.\mathrm{H}_{2} \mathrm{PO}_{4}^{-}\right)$were investigated by $\mathrm{UV}-\mathrm{Vis}$ and ${ }^{1} \mathrm{H}$ NMR spectroscopy in DMSO. The proton resonance signals of sensor $\mathrm{L} 1$ and $\mathrm{F}^{-}$ greatly changed positions when compared to those of anions. The solution color of sensor L1 changed from pale yellow to orange in the presence of $\mathrm{F}^{-}$. The UV-Vis results indicate that sensor $\mathrm{L} 1$ and $\mathrm{F}^{-}$ ions underwent an internal charge transfer process. The stoichiometric complex was confirmed by Job's method, revealing a 1:1 formation for sensor L1 and fluoride. Our results show that sensor L1 is highly selective for fluoride ions over other anions.
\end{abstract}

Keywords: 3,5-dihydroxytoluene derivative; hydrogen bonding interaction; single crystal X-ray; $\mathrm{F}^{-}$ ion sensor; sensor L1

\section{Introduction}

Currently, anion sensors have been the subject of considerable interest for their numerous roles in various processes in the fields of biology, catalysis, industry, and environmental protection. Anion sensors have also been used in devices such as television screens, as well as in monitoring and microelectronic sensors [1-5]. Researchers are interested in anion sensors with different dimensional structures, such as 2- and 3-dimensional patterns on carbon nanotubes and MOF structures [6,7]. For example, many binding units in the molecules amide, amine, thiourea, pyrrole, urea, hydroxyl, and boronic moieties are bound to anions through hydrogen bonding, anion $\pi$ interaction, electrostatic force, cleavage bonds, and Lewis acid-base interactions [8-16]. Fluoride ions are important anions because they assist in the growth of bones and teeth. However, when a considerable number of fluoride ions remain in the human body, it can cause a variety of diseases such as bone, kidney, and gastrointestinal disorders $[17,18]$. The sensor-anion recognition can be observed in many processes such as internal charge transfers, twisted intramolecular charge transfers, and excited state intramolecular proton transfers [19-21]. 3,5-dihydroxytoluene is known as an orcinol compound. Orcinol derivatives have important roles in many applications, such as for pharmaceutical and medical functions [22-27]. Among orcinol crystal structures, 
there are many polymorphs, pseudopolymorphs, and co-crystals of orcinols with different co-formers such as urea, acridine, and 4-cyanopyridine. They exhibit three possible conformations (i.e., "anti-anti", "syn-anti", and "syn-syn") through the packing modes of hydrogen bonds [28]. The co-crystal of an orcinol with 1,2-di(4-pyridyl)ethane can be observed in the pattern of 1D zig-zag chains that are interconnected to form a 2D layer structure by $\mathrm{C}-\mathrm{H}-\pi$ and $\pi-\pi$ interactions. The other co-crystal of an orcinol with 1,2-di(4pyridyl)ethylene is formed by a $0 \mathrm{D}$ four component complex through hydrogen bonds [23]. The advantage of crystals of orcinol compounds and their derivatives is that they allow for the design of synthetic sensors for anion detection. Orcinolic sensors consist of substituent groups, such as $-\mathrm{NO}_{2}$ withdrawing groups, that help binding sites provide more acidic protons of the $\mathrm{NH}$ group in the molecule and result in a strong binding interaction with anions. Among the related literatures, Singh and coworkers prepared two new receptors based on 4-nitrobenzylidenes with a highly selective binding ability to $\mathrm{F}^{-}, \mathrm{AcO}^{-}$, and $\mathrm{H}_{2} \mathrm{PO}_{4}{ }^{-}$[29]. Erdemir et al. synthesized two new colorimetric receptors bearing one or two nitrophenyl urea moieties that specifically bound to the $\mathrm{F}^{-}$ion, rather than other anions [30].

Here, we investigate the synthesis and crystallization of sensor L1, 2-(3-(hexyloxy)-5methylphenoxy)-N-(4-nitrophenyl)acetamide, containing 3,5-dihydroxytoluene as a backbone and amide moiety as a binding site for anions. Sensor L1 was characterized by ${ }^{1} \mathrm{H}$, ${ }^{13} \mathrm{C}$ NMR, ESI-MS, FT-IR, and elemental analysis. In addition, the complexation studies between sensor L1 and different anions were conducted using ${ }^{1} \mathrm{H}-\mathrm{NMR}$ and UV-Visible spectroscopy.

\section{Experiment}

\subsection{Materials}

All of the synthesises were used without further purification. In the titration experiment, all anions were added in the form of tetrabutylammonium (TBA) salts, which were purchased from Sigma-Aldrich Co., St. Louis, USA. Column chromatography was performed using silica gel (70-230 mesh).

\subsection{Apparatus}

Elemental analysis (CHNS/O) was carried out by Thermo Scientific ${ }^{\text {TM }}$ FLASH 2000, Cambridge, United Kingdom. MS was performed by Agilent 1100 Series LC/MSD Trap Karlsruhe, Germany. Elemental analysis informed the percent of elements in the product. Infrared spectra $\left(4000-400 \mathrm{~cm}^{-1}\right)$ were obtained by a Perkin Elmer system 2000 Fourier transform infrared spectrometer, Singapore. Infrared spectra express the functional groups of the molecules. ${ }^{1} \mathrm{H}$ and ${ }^{13} \mathrm{C}$ NMR spectra were obtained by a Bruker, AVANCE III HD $400 \mathrm{MHz}$ NMR spectrometer, Fällanden, Switzerland. ${ }^{1} \mathrm{H}$ and ${ }^{13} \mathrm{C}$ NMR spectra exhibit the resonance signals of the types of protons and carbons. UV-Vis spectra were recorded on a Shimadzu spectrophotometer, Kyoto, Japan. UV-Vis spectra display the absorption bands relate to the type of transitions between HOMO and LUMO.

\subsection{X-ray Crystallography}

Crystal of sensor L1 was selected under microscope and mounted on a Bruker D8 QUEST CMOS PHOTON II, Bremen, Germany, with graphite monochromated Mo-K $\alpha$ $(\lambda=0.71073 \AA)$ radiation at $296 \mathrm{~K}$. Data reduction was performed with SAINT and SADABS [31]. The integrity of the symmetry was determined using PLATON [32]. The structure was solved using the ShelXT structure solution program with combined Patterson and dualspace recycling methods [33] and refined using least squares with ShelXL [34]. All non-H atoms were refined anisotropically. Mercury software was used to generate the graphic molecules [35]. 


\subsection{Synthesis of 2-(3-(Hexyloxy)-5-Methylphenoxy)-N-(4-Nitrophenyl)acetamide, Sensor L1}

The complete synthesis can be viewed in Scheme 1.

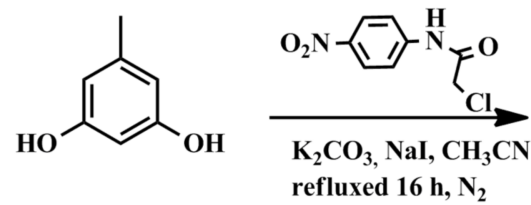

refluxed $16 \mathrm{~h}, \mathrm{~N}_{2}$<smiles>Cc1cc(O)cc(OCC(=O)Nc2ccc([N+](=O)[O-])cc2)c1</smiles>

$\mathrm{Br}$ $\mathrm{K}_{2} \mathrm{CO}_{3}, \mathrm{NaI}, \mathrm{CH}_{3} \mathrm{CN}$ refluxed $10 \mathrm{~h}, \mathrm{~N}_{2}$

$\downarrow$

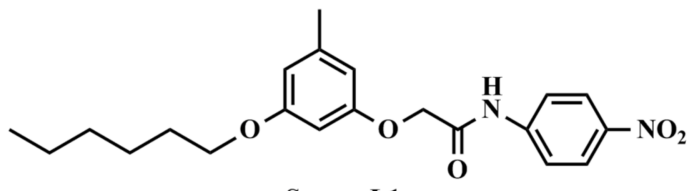

Sensor L1

Scheme 1. Synthetic pathway of sensor L1.

\subsubsection{2-(3-Hydroxy-5-Methylphenoxy)-N-(4-Nitrophenyl)acetamide}

3,5-Dihydroxytoluene $(1.50 \mathrm{~g})$, potassium carbonate $(3.0 \mathrm{~g})$, and 2-chloro-N-(4nitrophenyl)acetamide ( $2.5 \mathrm{~g}$ ) synthesized, in accordance with Wen et al. [36], were dissolved and stirred in $35 \mathrm{~mL}$ of $\mathrm{CH}_{3} \mathrm{CN}$ with the addition of sodium iodide as a catalyst.

Then, the reaction mixture was stirred and refluxed at $110^{\circ} \mathrm{C}$ for $16 \mathrm{~h}$. The reaction mixture was extracted with $\mathrm{H}_{2} \mathrm{O}$ and $20 \mathrm{~mL} \mathrm{CH}_{2} \mathrm{Cl}_{2}$ three times. The combined organic phase was dried with anhydrous $\mathrm{Na}_{2} \mathrm{SO}_{4}$. After the solvent was removed, the residue was purified by column chromatography over silica gel using dichloromethane:ethyl acetate (9:1) as an eluent to afford a yellow solid with a yield of $85 \%$. mp. $=142-143{ }^{\circ} \mathrm{C} .{ }^{1} \mathrm{H}$ NMR (400 MHz, DMSO-d6): $810.64(\mathrm{~s}, 1 \mathrm{H},-\mathrm{NH}), 9.33(\mathrm{~s}, 1 \mathrm{H},-\mathrm{OH}), 8.23(\mathrm{~d}, \mathrm{~J}=9.40 \mathrm{~Hz}$, $2 \mathrm{H},-\mathrm{ArH}), 7.91(\mathrm{~d}, \mathrm{~J}=9.20 \mathrm{~Hz}, 2 \mathrm{H},-\mathrm{ArH}), 6.26(\mathrm{~s}, 1 \mathrm{H},-\mathrm{ArH}), 6.22(\mathrm{~s}, 1 \mathrm{H},-\mathrm{ArH}), 6.19(\mathrm{t}$, $1 \mathrm{H},-\mathrm{ArH}), 4.64\left(\mathrm{~s}, 2 \mathrm{H},-\mathrm{CH}_{2}\right), 2.18\left(\mathrm{~s}, 3 \mathrm{H},-\mathrm{CH}_{3}\right){ }^{13} \mathrm{C} \mathrm{NMR}\left(100 \mathrm{MHz}, \mathrm{CDCl}_{3}-d\right): \delta 167.80$, $158.77,158.35,144.63,142.53,139.59,124.92,119.33,106.39,99.21,67.08,21.30$. FT-IR (KBr, $\mathrm{cm}^{-1}$ ): $\vee 3365$ (N-H stretching), 2921 (C-H stretching), 1710 (C=O stretching), 1559 (N-O stretching), 1503 (C=CAr stretching), 1334 ( $\mathrm{N}-\mathrm{O}$ stretching), 1255 (C-N stretching), 1172 (C-O stretching), 1109 (C-O stretching alcohol). ESI-MS: $\mathrm{m} / \mathrm{z}$ calculated for $\mathrm{C}_{15} \mathrm{H}_{14} \mathrm{~N}_{2} \mathrm{O}_{5}$ ([M $\left[\mathrm{M}^{+}\right]$): 302.1 found 302.6 Element analysis for $\mathrm{C}_{15} \mathrm{H}_{14} \mathrm{~N}_{2} \mathrm{O}_{5}$ (\%): $\mathrm{C} 59.60, \mathrm{H} 4.67, \mathrm{~N} 9.27$ found: C 59.55, H 4.65, N 9.06.

\subsubsection{2-(3-(Hexyloxy)-5-Methylphenoxy)-N-(4-Nitrophenyl)acetamide, (Sensor L1)}

2-(3-hydroxy-5-methylphenoxy)-N-(4-nitrophenyl)acetamide) (0.50 g) and potassium carbonate $(1.5 \mathrm{~g})$ were dissolved in $30 \mathrm{~mL}$ of acetonitrile and stirred for $1 \mathrm{~h}$ under a $\mathrm{N}_{2}$ atmosphere. Then, a solution of 1-bromohexane $(0.6 \mathrm{~mL})$ and sodium iodide was added dropwise. The mixture was stirred and refluxed at $110^{\circ} \mathrm{C}$ for $10 \mathrm{~h}$. The reaction mixture was extracted with water and dichloromethane $50 \mathrm{~mL}$ three times. The combined organic phase was dried with anhydrous $\mathrm{Na}_{2} \mathrm{SO}_{4}$. After the solvent was removed, the residue was purified by column chromatography over silica gel using dichloromethane:ethyl acetate (9:1) as an eluent to give a yellow solid of sensor L1 with a yield of $86 \% . \mathrm{mp} .=156-157^{\circ} \mathrm{C}$. ${ }^{1} \mathrm{H}$ NMR (400 MHz, DMSO-d6): $\delta 10.64(\mathrm{~s}, 1 \mathrm{H},-\mathrm{NH}), 8.24$ (d, J = $\left.9.20 \mathrm{~Hz}, 2 \mathrm{H},-\mathrm{ArH}\right), 7.91(\mathrm{~d}$, $\mathrm{J}=9.30 \mathrm{~Hz}, 2 \mathrm{H},-\mathrm{ArH}), 6.40(\mathrm{~s}, 1 \mathrm{H},-\mathrm{ArH}), 6.38(\mathrm{~s}, 1 \mathrm{H},-\mathrm{ArH}), 6.36(\mathrm{t}, 1 \mathrm{H},-\mathrm{ArH}), 4.73(\mathrm{~s}, 2 \mathrm{H}$, $\left.-\mathrm{CH}_{2}\right), 3.91\left(\mathrm{t}, 2 \mathrm{H},-\mathrm{CH}_{2}\right), 2.23\left(\mathrm{~s}, 3 \mathrm{H},-\mathrm{CH}_{3}\right), 2.08\left(\mathrm{~m}, 2 \mathrm{H},-\mathrm{CH}_{2}\right), 1.77\left(\mathrm{~m}, 2 \mathrm{H},-\mathrm{CH}_{2}\right), 1.32$ $\left(\mathrm{m}, 4 \mathrm{H},-\mathrm{CH}_{2}\right), 0.86\left(\mathrm{t}, 3 \mathrm{H},-\mathrm{CH}_{3}\right) .{ }^{13} \mathrm{C}$ NMR $\left(100 \mathrm{MHz}, \mathrm{CDCl}_{3}-d\right): \delta 167.00,160.65,157.81$, 144.16, 142.70, 141.11, 125.26, 119.60, 109.69, 107.70, 99.22, 68.30, 67.66, 31.70, 29.32, 25.58, 
22.74, 21.96, 14.17. FT-IR ( $\left.\mathrm{KBr}, \mathrm{cm}^{-1}\right)$ : $v 3329$ (N-H stretching), 2922 (C-H stretching), 1680 (C=O stretching), 1559 (N-O stretching), 1504 (C-CAr stretching), 1404 (C-O in plan bending), 1342 (N-O stretching), 1296 (C-N stretching), 1167 (C-O stretching) ESI-MS: $\mathrm{m} / \mathrm{z}$ calculated for $\mathrm{C}_{21} \mathrm{H}_{26} \mathrm{~N}_{2} \mathrm{O}_{5}{ }^{-} \mathrm{H}^{+}\left(\left[\mathrm{M}-\mathrm{H}^{+}\right]\right)$: 387.2: found 387.3. Element analysis for $\mathrm{C}_{21} \mathrm{H}_{26} \mathrm{~N}_{2} \mathrm{O}_{5}$ : C 65.27, H 6.78, N 7.25 found: C 64.83, H 6.64, N 7.00.

\section{Results and Discussion}

\subsection{Crystal Structure and Structural Description}

The light-yellow block-shaped crystals of sensor L1 were grown in the mixture of dichloromethane and hexane (1:1) solvents at room temperature. The crystal data and experimental refinement parameters of sensor L1 have been summarized in Table 1. Figure 1 exhibits the molecular structure of sensor L1 with atom labeling. The aromatic ring of 3,5-dihydroxyl toluene is combined with 4-nitrobenzene moiety by the bridging group of methylene amide with torsion angles O1-C8-C9-N1 of $17.77^{\circ}$ and O1-C8-C9-O3 of $-163.61^{\circ}$. In this conformation, the $-\mathrm{NH}$ group and oxygen atom from the previous hydroxyl group (O1) are on the same side, while the -CO group is on the opposite side. The dihedral angle between 3,5-dihydroxyl toluene and 4-nitrobenzene mean planes is $5.60^{\circ}$, indicating that the aromatics are almost coplanar. Additionally, another hydroxyl group of 3,5-dihydroxyl toluene at the position of $\mathrm{C} 3$ reacted with hexyl bromide, producing alkyl ether with torsion angles $\mathrm{C} 2-\mathrm{C} 3-\mathrm{O} 2-\mathrm{C} 16$ of $2.09^{\circ}$.

Table 1. Crystal data and structure refinement for Sensor L1.

\begin{tabular}{|c|c|}
\hline Compound & Sensor L1 \\
\hline CCDC Number & 1420420 \\
\hline Empirical Formula & $\mathrm{C}_{21} \mathrm{H}_{26} \mathrm{~N}_{2} \mathrm{O}_{5}$ \\
\hline Formula Weight & 386.44 \\
\hline Temperature & 296 \\
\hline Wavelength $(\AA)$ & 0.71073 \\
\hline Crystal System & monoclinic \\
\hline Space Group & $P 2_{1}$ \\
\hline a $(\AA)$ & $9.7080(6)$ \\
\hline $\mathrm{b}(\AA)$ & $5.3052(3)$ \\
\hline c $(\AA)$ & 19.8563(13) \\
\hline$\alpha\left(^{\circ}\right)$ & 90 \\
\hline$\beta\left(^{\circ}\right)$ & $98.554(2)$ \\
\hline$\gamma\left({ }^{\circ}\right)$ & 90 \\
\hline Volume / $\AA^{3}$ & 1011.28(11) \\
\hline $\mathrm{Z}$ & 2 \\
\hline Density (calculated) $\left(\mathrm{g} / \mathrm{cm}^{3}\right)$ & 1.269 \\
\hline Absorption Coefficient $\left(\mathrm{mm}^{-1}\right)$ & 0.091 \\
\hline $\mathrm{F}(000)$ & 412.0 \\
\hline Crystal Size $\left(\mathrm{mm}^{3}\right)$ & $0.26 \times 0.14 \times 0.14$ \\
\hline Theta Range for Data Collection $\left(^{\circ}\right)$ & 6.224 to 52.792 \\
\hline Index Ranges & $-10 \leq \mathrm{h} \leq 12,-6 \leq \mathrm{k} \leq 6,-24 \leq 1 \leq 24$ \\
\hline
\end{tabular}


Table 1. Cont.

\begin{tabular}{cc}
\hline Compound & Sensor L1 \\
\hline Reflections Collected & 12,231 \\
\hline Independent Reflections & $4117\left[\mathrm{R}_{\text {int }}=0.0402\right]$ \\
\hline Max. and Min. Transmission & 0.7454 and 0.6568 \\
\hline Data/Restraints/Parameters & $4117 / 1 / 255$ \\
\hline Goodness-of-fit on $\mathrm{F}^{2}$ & 1.066 \\
\hline Final R Indices [I $>$ 2sigma(I)] & $\mathrm{R} 1=0.0437, \mathrm{wR} 2=0.0873$ \\
\hline $\mathrm{R}$ Indices (all data) & $\mathrm{R} 1=0.0733, \mathrm{wR} 2=0.0976$ \\
\hline Largest Diff. Peak and Hole & $0.15 /-0.14$ e $\AA^{-3}$
\end{tabular}

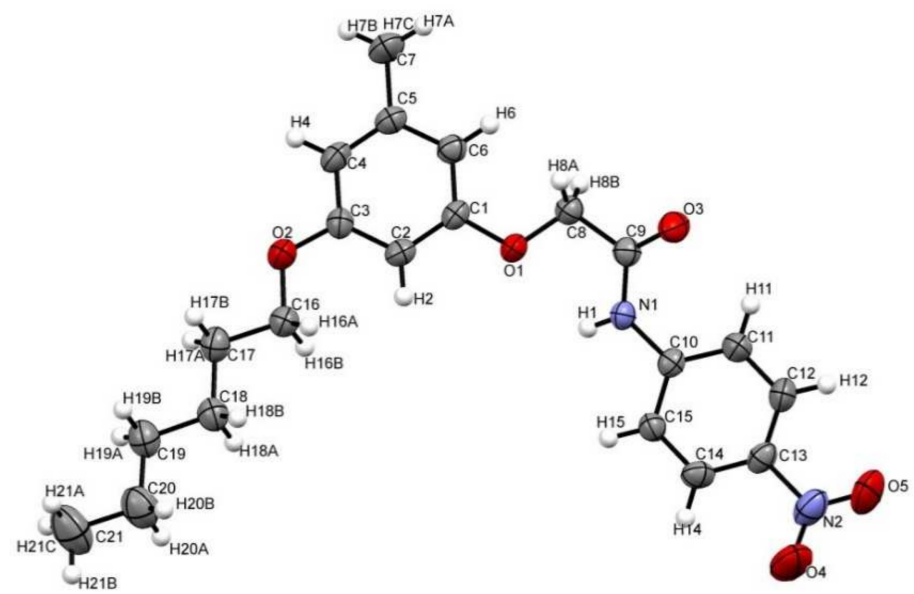

Figure 1. The molecular structure of sensor L1 with atom labeling and 50\% probability displacement ellipsoids.

The alkyl chain (C16-C21) is in a zig-zag configuration with torsion angles in the range of $177.47-179.69^{\circ}$, and the dihedral angle between the plane of the alkyl chain and the aromatic plane of 3,5-dihydroxyl toluene is $7.83^{\circ}$. This indicates that the two functional groups on the toluene ring are almost coplanar.

The crystal packing is strongly supported by two hydrogen bonds between the $-\mathrm{NH}$ amide group, and the $-\mathrm{CH}$ in nitrobenzene with oxygen of the carbonyl group in amide of adjacent molecules $(\mathrm{N}-\mathrm{H} \cdots \mathrm{O}$, and $\mathrm{C}-\mathrm{H} \cdots \mathrm{O})$ with a six membered ring pattern as shown in Figure 2 and Table 2.

Table 2. Hydrogen-bond geometry $\left(\AA,^{\circ}\right)$.

\begin{tabular}{ccccc}
\hline $\mathbf{D}-\mathbf{H} \cdots \mathbf{A}$ & $\mathbf{D}-\mathbf{H}$ & $\mathbf{H} \cdots \mathbf{A}$ & $\mathbf{D} \cdots \mathbf{A}$ & $\mathbf{D}-\mathbf{H} \cdots \mathbf{A}$ \\
\hline $\mathrm{N} 1-\mathrm{H} 1 \cdots \mathrm{O}^{\mathrm{i}}$ & 0.86 & 2.37 & $3.096(3)$ & 143 \\
\hline $\mathrm{C} 15-\mathrm{H} 15 \cdots \mathrm{O}^{\mathrm{i}}$ & 0.930 & 2.636 & 3.178 & 117.88 \\
\hline $\mathrm{C} 16-\mathrm{H} 16 \mathrm{~B} \cdots \mathrm{C}^{\mathrm{i}}$ & 0.970 & 2.882 & 3.793 & 156.87 \\
\hline $\mathrm{C} 8-\mathrm{H} 8 \mathrm{~B} \cdots \mathrm{C} 10^{\mathrm{ii}}$ & 0.969 & 2.888 & 3.764 & 150.69 \\
\hline
\end{tabular}

Symmetry code: i: $x, y+1, z$, ii: $-1-x,-1 / 2+y,-1-z$. 


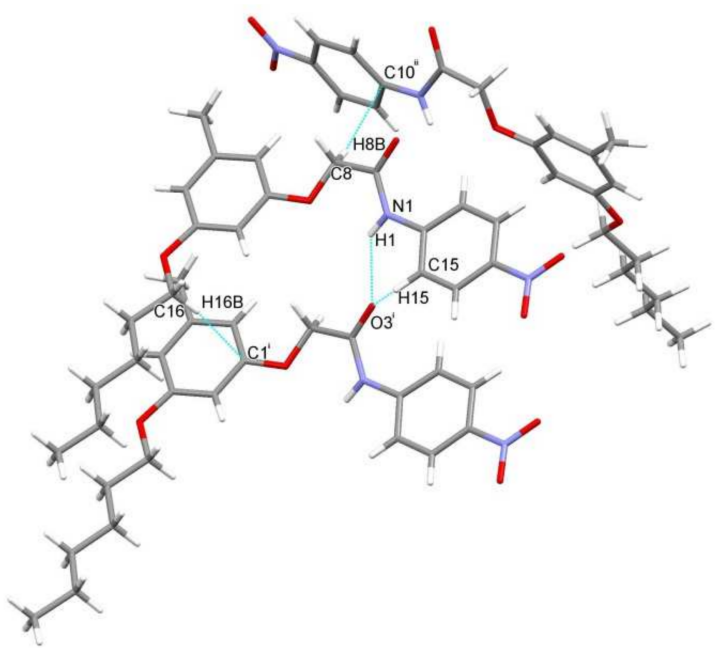

Figure 2. The strong hydrogen bonds of $\mathrm{N}-\mathrm{H} \cdots \mathrm{O}$ and $\mathrm{C}-\mathrm{H} \cdots \mathrm{O}$ and the weak $\mathrm{C}-\mathrm{H} \cdots \mathrm{C}$ hydrogen bond. Hydrogen bonds are shown as dashed blue lines.

In addition, the crystal structure is also supported by a weak hydrogen bond between $\mathrm{C}-\mathrm{H}$ of the methylene group and carbon atoms $(\mathrm{C}-\mathrm{H} \cdots \mathrm{C})$, which are close to the high electronegativity atoms, $\mathrm{N}$ and $\mathrm{O}$ (Figure 2 and Table 2). The crystal packing through strong and weak hydrogen bonding interaction among the adjacent molecules in the direction of $x$, $\mathrm{y}+1$, $\mathrm{z}$ shows a one-dimensional array along the $b$-axis in Figure $3 \mathrm{a}$. If a weaker hydrogen bond $(\mathrm{C}-\mathrm{H} \cdots \mathrm{C})$ with neighbors is added in the direction of $-1-\mathrm{x},-1 / 2+\mathrm{y},-1-\mathrm{z}$, the crystal structure will appear different to that in Figure $3 b-d$. The selected bond length and bond angle of sensor L1 have been provided in Table 3.

(a)

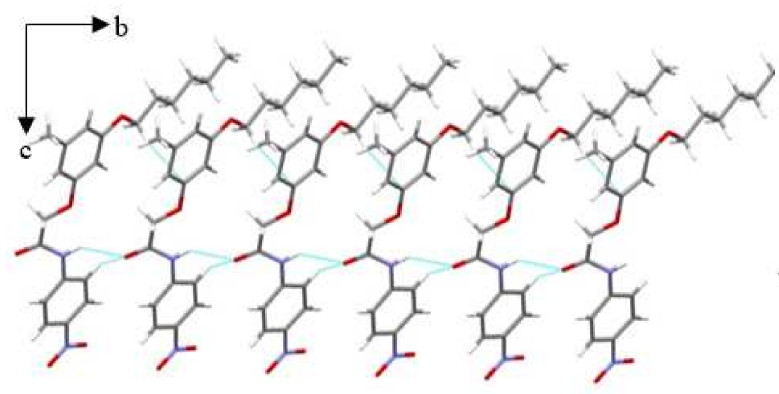

(b)

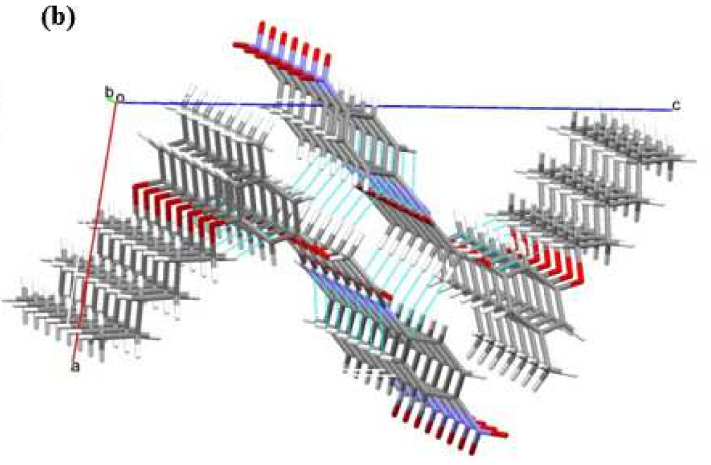

(d)

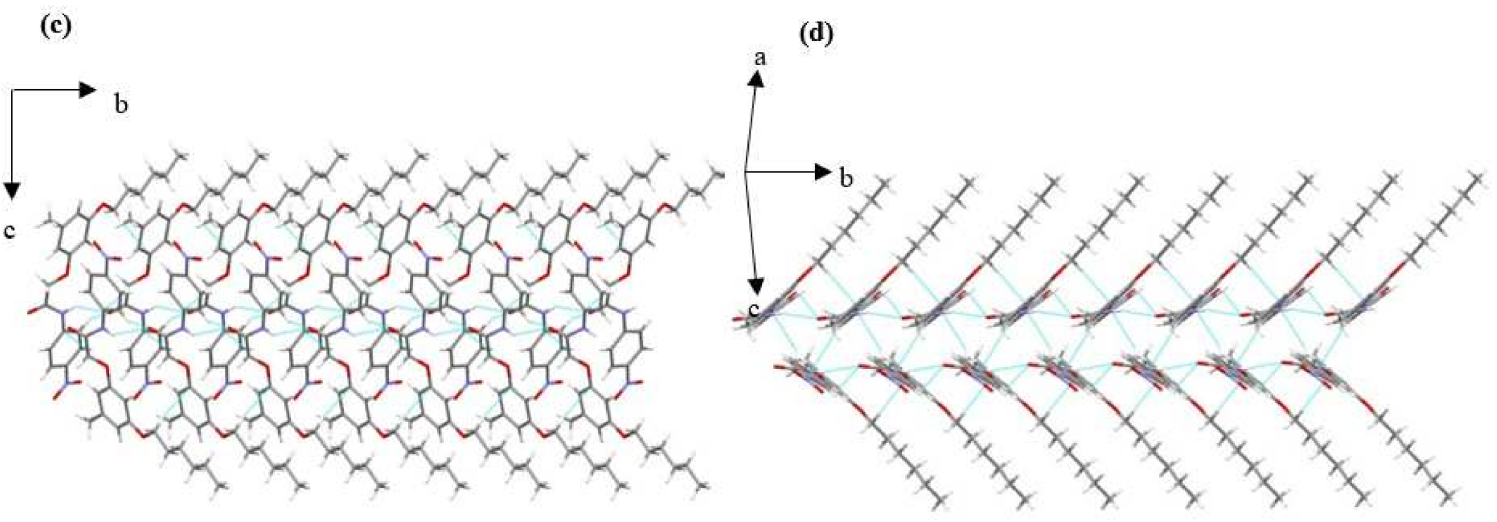

Figure 3. (a) The crystal structure packing along the $a$-axis showing interaction between adjacent molecules only in the direction of $\mathrm{x}, \mathrm{y}+1, \mathrm{z} ;(\mathbf{b}-\mathbf{d})$ the packing of the crystal structure in different directions. 
Table 3. Selected bond length $(\AA)$ and bond angle of sensor L1.

\begin{tabular}{|c|c|c|c|}
\hline Parameters & Bond Length (Å) & Parameters & Bond Length ( $\AA$ ) \\
\hline $\mathrm{O} 1-\mathrm{C} 1$ & $1.384(3)$ & C5-C6 & $1.393(4)$ \\
\hline $\mathrm{O} 1-\mathrm{C} 8$ & 1.404(3) & $\mathrm{C} 5-\mathrm{C} 7$ & $1.513(4)$ \\
\hline $\mathrm{O} 2-\mathrm{C} 3$ & $1.363(3)$ & $\mathrm{C} 8-\mathrm{C} 9$ & $1.505(4)$ \\
\hline $\mathrm{O} 2-\mathrm{C} 16$ & $1.435(4)$ & $\mathrm{C} 10-\mathrm{C} 11$ & $1.385(4)$ \\
\hline O3-C9 & $1.214(3)$ & C10-C15 & $1.391(4)$ \\
\hline $\mathrm{O} 4-\mathrm{N} 2$ & $1.218(4)$ & $\mathrm{C} 11-\mathrm{C} 12$ & $1.378(4)$ \\
\hline O5-N2 & $1.208(4)$ & $\mathrm{C} 12-\mathrm{C} 13$ & $1.374(4)$ \\
\hline Atom-atom-atom & Angle $\left(/^{\circ}\right)$ & Atom-atom-atom & Angle $\left(/^{\circ}\right)$ \\
\hline $\mathrm{C} 1-\mathrm{O} 1-\mathrm{C} 8$ & $116.6(2)$ & O3-C9-N1 & $124.3(2)$ \\
\hline $\mathrm{C} 3-\mathrm{O} 2-\mathrm{C} 16$ & $117.6(2)$ & O3-C9-C8 & $119.4(2)$ \\
\hline C9-N1-C10 & $126.0(2)$ & N1-C9-C8 & $116.3(2)$ \\
\hline $\mathrm{O} 4-\mathrm{N} 2-\mathrm{C} 13$ & $117.3(3)$ & C11-C10-N1 & $122.1(2)$ \\
\hline O5-N2-O4 & $123.9(3)$ & C11-C10-C15 & $119.3(2)$ \\
\hline O5-N2-C13 & $118.8(3)$ & C15-C10-N1 & $118.6(2)$ \\
\hline $\mathrm{O} 1-\mathrm{C} 1-\mathrm{C} 2-\mathrm{C} 3$ & $-179.6(3)$ & $\mathrm{C} 4-\mathrm{C} 5-\mathrm{C} 6-\mathrm{C} 1$ & $-1.2(4)$ \\
\hline O1-C1-C6-C5 & $179.5(2)$ & $\mathrm{C} 6-\mathrm{C} 1-\mathrm{C} 2-\mathrm{C} 3$ & $0.0(4)$ \\
\hline O1-C8-C9-O3 & $-163.6(3)$ & C7-C5-C6-C1 & 179.5(3) \\
\hline O1-C8-C9-N1 & $17.7(3)$ & $\mathrm{C} 8-\mathrm{O} 1-\mathrm{C} 1-\mathrm{C} 2$ & $-160.3(2)$ \\
\hline $\mathrm{O} 2-\mathrm{C} 3-\mathrm{C} 4-\mathrm{C} 5$ & $177.0(3)$ & C8-O1-C1-C6 & $20.1(4)$ \\
\hline O2-C16-C17-C18 & $-176.9(3)$ & C9-N1-C10-C11 & $-29.2(4)$ \\
\hline O4-N2-C13-C12 & 179.1(3) & C9-N1-C10-C15 & $151.6(3)$ \\
\hline O4-N2-C13-C14 & $0.3(5)$ & C10-N1-C9-C3 & $0.8(4)$ \\
\hline O5-N2-C13-C12 & $-2.4(4)$ & C10-N1-C9-C8 & $179.4(2)$ \\
\hline
\end{tabular}

3.2. Interaction between Sensor L1 and Various Anions Using UV-Vis and ${ }^{1} H$ NMR Spectroscopy 3.2.1. Colorimetric Sensor L1

The colorimetric anion recognition of sensor L1 was investigated by the naked-eye at an ambient temperature in the DMSO solution. The concentration of sensor L1 was $5 \times 10^{-3} \mathrm{M}$. It was then supplemented with four equiv. of various anions such as $\mathrm{F}^{-}$, $\mathrm{Cl}^{-}, \mathrm{Br}^{-}, \mathrm{CH}_{3} \mathrm{COO}^{-}, \mathrm{C}_{6} \mathrm{H}_{5} \mathrm{COO}^{-}$and $\mathrm{H}_{2} \mathrm{PO}_{4}^{-}$(tetrabutylammonium salt), as depicted in Figure 4. The color of the sensor L1 solution changed from pale yellow to orange upon addition of $\mathrm{F}^{-}$. This result might be due to the small size and high negative charge density of $\mathrm{F}^{-}$, which induces the strongest interaction with sensor $\mathrm{L} 1$. For the case of $\mathrm{CH}_{3} \mathrm{COO}^{-}$, $\mathrm{C}_{6} \mathrm{H}_{5} \mathrm{COO}^{-}$, and $\mathrm{H}_{2} \mathrm{SO}_{4}{ }^{-}$, the color of the sensor L1 solution changed from pale yellow to intense yellow. There was no color change in sensor L1 with the addition of $\mathrm{Cl}^{-}$and $\mathrm{Br}^{-}$. The ${ }^{1} \mathrm{H}$ NMR spectrum for sensor L1 in DMSO- $d_{6}$ can be found in Supplementary Material. 


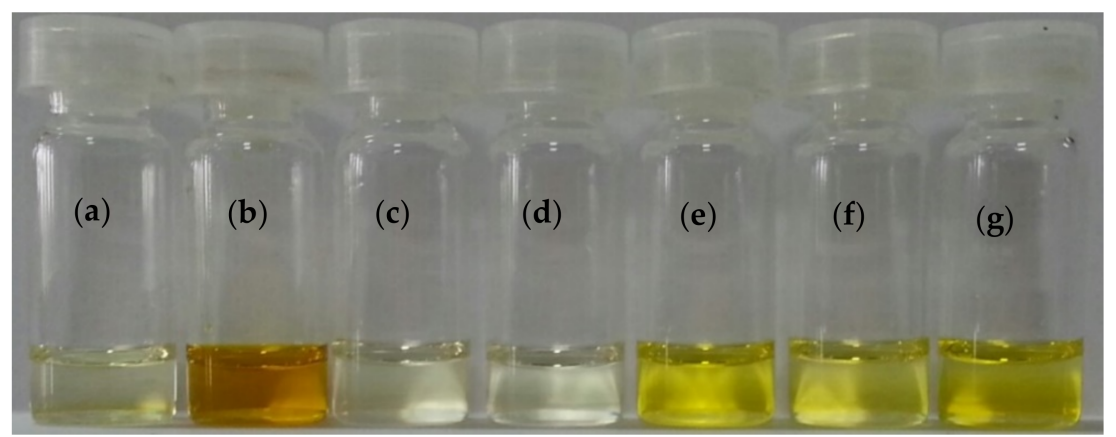

Figure 4. The visible color changes in sensor L1 in DMSO solution $\left(5.0 \times 10^{-3} \mathrm{M}\right)$ upon addition of 4 equiv. of anions in form of TBA salts: from left to right (a) free sensor $\mathrm{L} 1 ;$ (b) $\mathrm{F}^{-}$; (c) $\mathrm{Cl}^{-}$; (d) $\mathrm{Br}^{-}$; (e) $\mathrm{CH}_{3} \mathrm{COO}^{-}$; (f) $\mathrm{C}_{6} \mathrm{H}_{5} \mathrm{COO}^{-}$; and $(\mathbf{g}) \mathrm{H}_{2} \mathrm{PO}_{4}{ }^{-}$.

\subsubsection{Interaction between Sensor L1 and Various Anions Using UV-Visible Spectroscopy}

The anion binding abilities of sensor L1 were studied using UV-Vis titration with various anions such as $\mathrm{F}^{-}, \mathrm{Cl}^{-}, \mathrm{Br}^{-}, \mathrm{CH}_{3} \mathrm{COO}^{-}, \mathrm{C}_{6} \mathrm{H}_{5} \mathrm{COO}^{-}$, and $\mathrm{H}_{2} \mathrm{PO}_{4}^{-}$(as tetrabutylammonium salts). The experiment was performed by preparing $5 \times 10^{-5} \mathrm{M}$ of sensor L1 in a dimethyl sulfoxide solution. There were two absorption bands of sensor L1 that exhibited a shoulder band at approximately $284 \mathrm{~nm}$ and a strong band at $327 \mathrm{~nm}$. Figure 5 shows the absorption spectra changes of sensor L1 in the presence of different fluoride ions (0-20 equiv.). With the addition of an increasing concentration of $\mathrm{F}^{-}$ions to the sensor L1 solution, the absorption bands at 284 and $327 \mathrm{~nm}$ gradually decreased. In addition, a new red shift absorption band at $446 \mathrm{~nm}$ was observed, corresponding to a new species of the deprotonated form in the solution. An isosbestic point at $378 \mathrm{~nm}$ indicated that the two formations of sensor L1 were normal and deprotonated species in the equilibrium [37,38]. These results indicate that the mechanism of sensor L1 and $\mathrm{F}^{-}$ions occurred under an internal charge transfer process [39]. The addition of other anions in the solution of sensor L1 caused a decrease only in the absorption bands at 284 and $327 \mathrm{~nm}$ because of weak interaction, as shown in Figure 6.

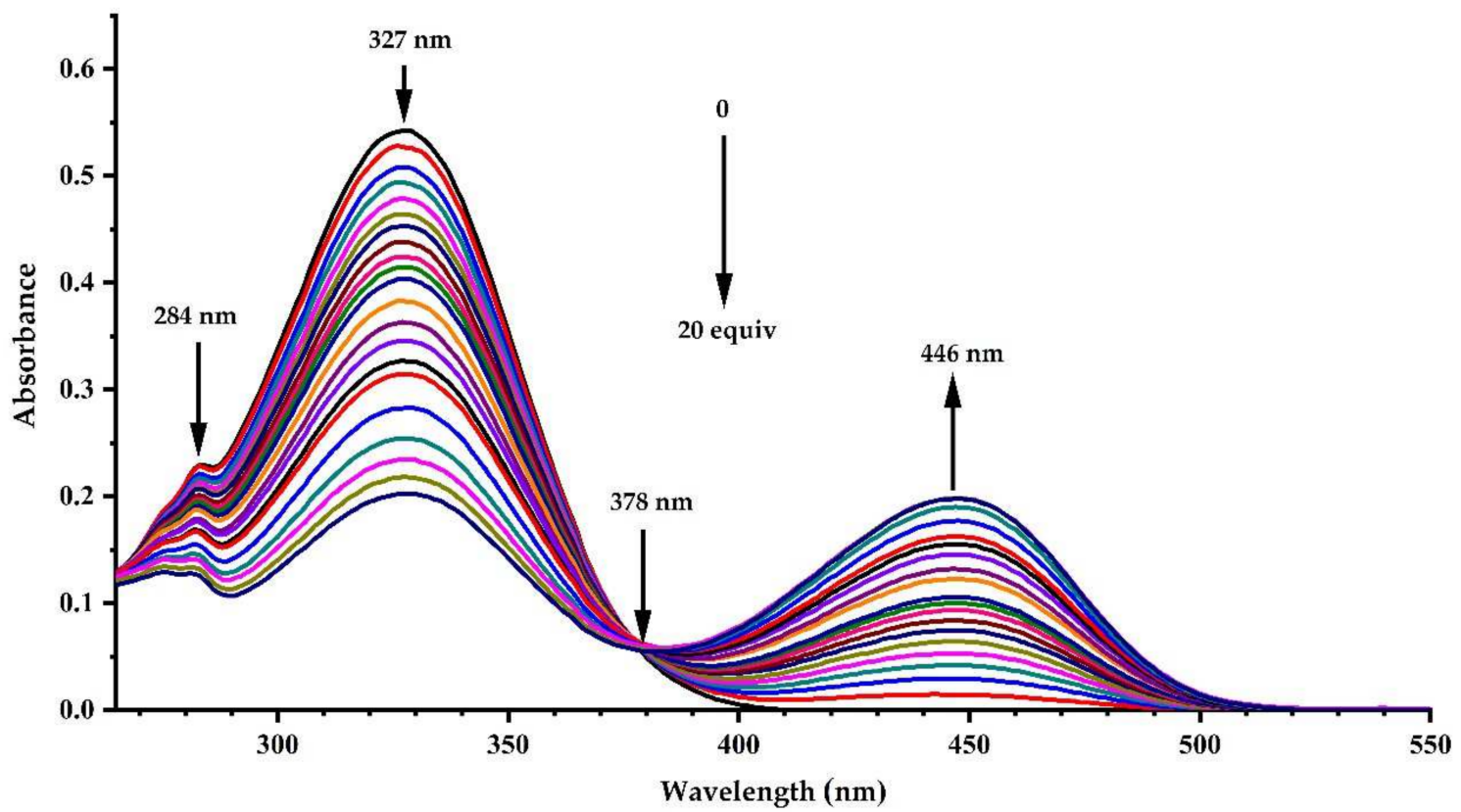

Figure 5. UV-Vis absorption spectra of sensor L1 $\left(5 \times 10^{-5} \mathrm{M}\right)$ in DMSO upon addition of $\mathrm{F}^{-}$in the range of 0 to 20 equivalents. 


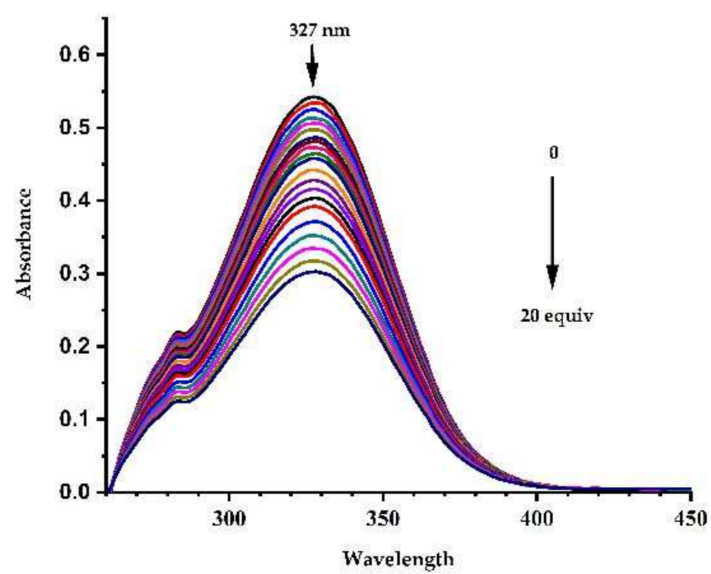

(a)

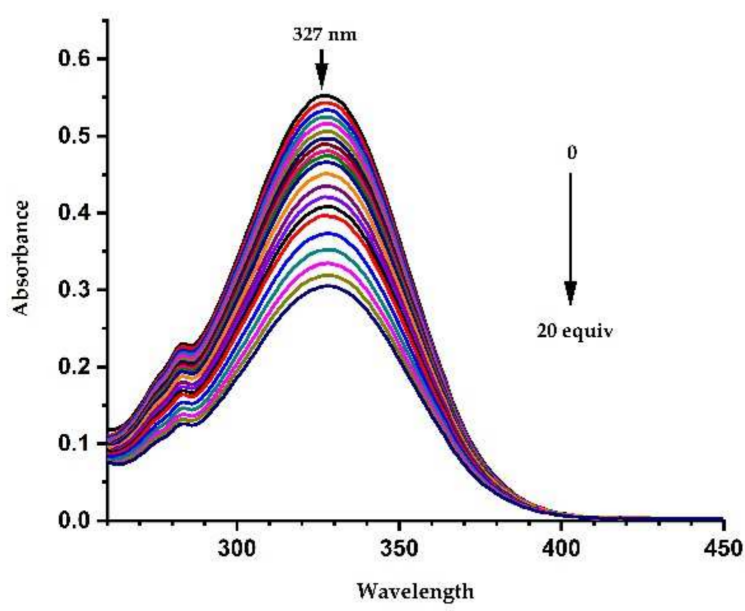

(b)

Figure 6. UV-Vis absorption spectra of sensor L1 $\left(5 \times 10^{-5} \mathrm{M}\right)$ in DMSO upon addition of (a) $\mathrm{CH}_{3} \mathrm{COO}^{-}$and $(\mathbf{b}) \mathrm{H}_{2} \mathrm{PO}_{4}^{-}$ in the range of $0-20$ equivalents.

In Figure 7, sensor L1 with $\mathrm{F}^{-}$ions exhibited an obvious new band at $446 \mathrm{~nm}$. With the other anions, the spectra of sensor L1 showed a decrease in the absorption band at 284 and $327 \mathrm{~nm}$ without the appearance of a new absorption band. This suggests that sensor $\mathrm{L} 1$ is selective for $\mathrm{F}^{-}$ions over other anions.

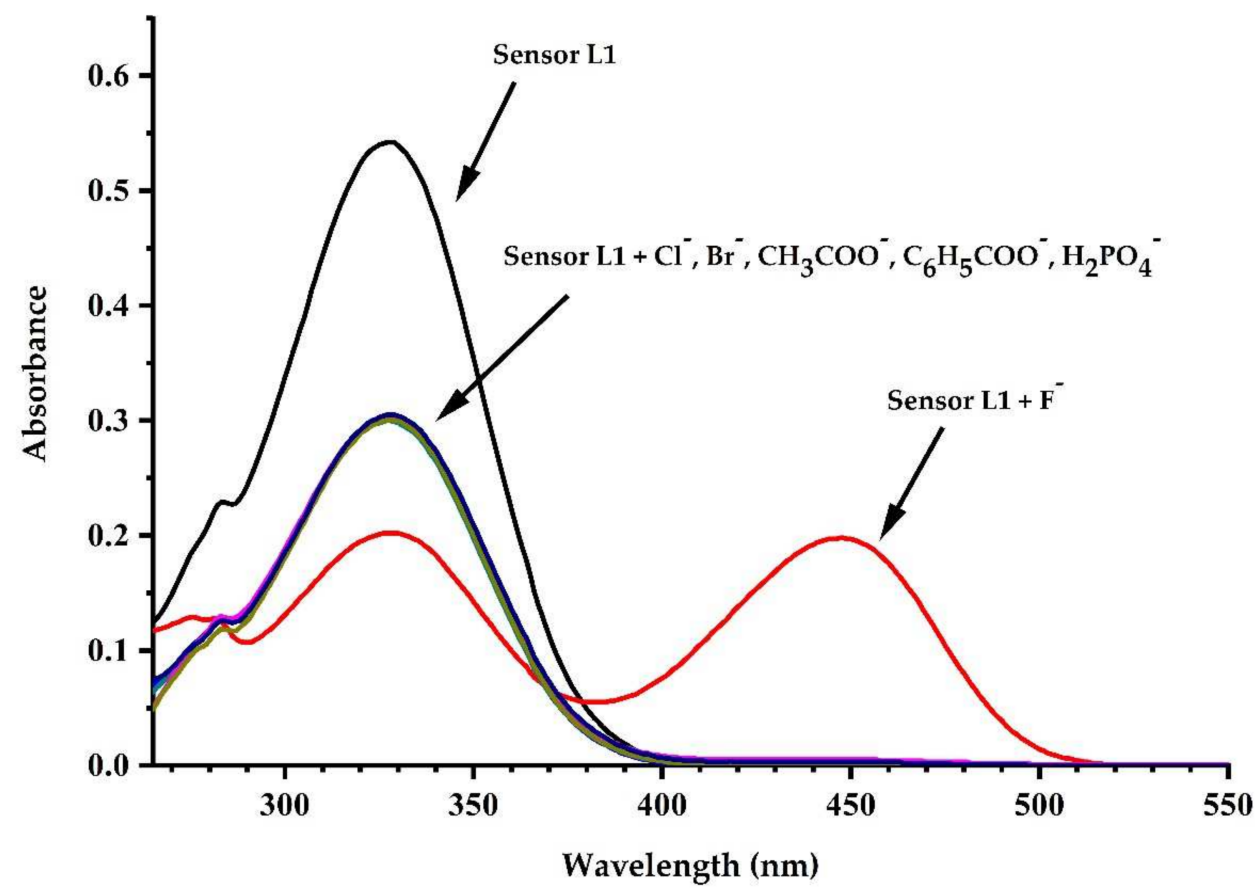

Figure 7. UV-Vis absorption spectra sensor L1 $\left(5 \times 10^{-5} \mathrm{M}\right)$ in DMSO upon the addition of 20 equivalents of various anions.

Job's analysis presumed that the maximum absorption point estimated at the 0.50 mole fraction of [sensor L1]/([sensor L1] $\left.+\left[\mathrm{F}^{-}\right]\right)$indicates a 1:1 formation between sensor L1 and fluoride ions as shown in Figure 8. 


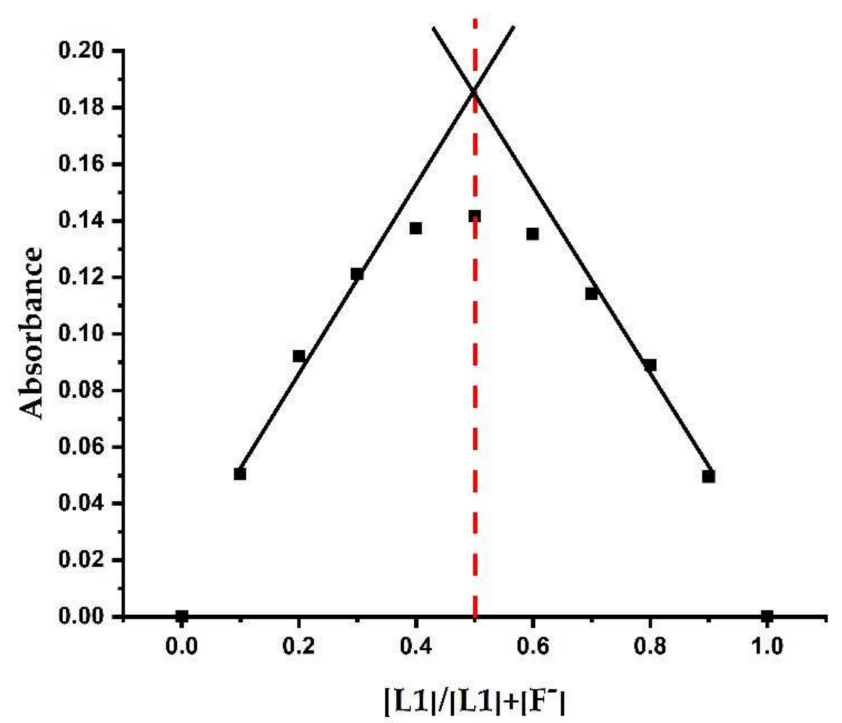

Figure 8. Job's plot of sensor L1 with fluoride ions.

\subsubsection{Interaction between Sensor L1 and Various Anions Using ${ }^{1} \mathrm{H}$ NMR Spectroscopy}

The interaction behavior of sensor $\mathrm{L} 1\left(5 \times 10^{-3} \mathrm{M}\right)$ with various anions such as $\mathrm{F}^{-}, \mathrm{Cl}^{-}$, $\mathrm{Br}^{-}, \mathrm{CH}_{3} \mathrm{COO}^{-}, \mathrm{C}_{6} \mathrm{H}_{5} \mathrm{COO}^{-}$and $\mathrm{H}_{2} \mathrm{PO}_{4}^{-}$(tetrabutylammonium salt) was investigated using ${ }^{1} \mathrm{H}$ NMR experiments in DMSO- $d_{6}$, as shown in Figure 9. The selected chemical shift assignments of sensor L1 have been listed in Table 4. Sensor L1 exhibited a sharp signal of the $\mathrm{NH}$ amide proton at $10.64 \mathrm{ppm}$. Upon addition of 4 equiv. $\mathrm{F}^{-}$to sensor L1, the $\mathrm{NH}$ amide proton disappeared when under the deprotonation process, as shown in Figure 9A. In addition, the signals of aromatic protons and $\mathrm{CH}_{2}$ protons shifted upfield due to an enhancement of electron density around their region. The ${ }^{1} \mathrm{H}$ NMR spectrum of sensor $\mathrm{L} 1$ with an $\mathrm{F}^{-}$ion considerably changed when compared with that of other anions. In the case of $\mathrm{CH}_{3} \mathrm{COO}^{-}, \mathrm{C}_{6} \mathrm{H}_{5} \mathrm{COO}^{-}$, and $\mathrm{H}_{2} \mathrm{PO}_{4}{ }^{-}$, the $\mathrm{NH}$ proton of sensor $\mathrm{L} 1$ also disappeared. However, the aromatic protons and $\mathrm{CH}_{2}$ protons hardly changed. In the presence of $\mathrm{Cl}^{-}$and $\mathrm{Br}^{-}$, the $\mathrm{NH}$ proton slightly shifted downfield due to weak hydrogen bonding interaction, and the aromatic protons and $\mathrm{CH}_{2}$ protons remained in unchangeable positions (Figure 9C,D).

Table 4. Selected chemical shift assignments of sensor L1.

\begin{tabular}{cc}
\hline Chemical Shifts (ppm) & Assignments \\
\hline 10.64 & NH Proton at Amide Group \\
\hline 8.24 and 7.91 & $\begin{array}{c}\text { CH Protons } \\
\text { (aromatic protons at nitroaniline) }\end{array}$ \\
\hline 6.40 & $\begin{array}{c}\text { CH Protons } \\
\text { (aromatic protons at 3,5-dihydroxy toluene) }\end{array}$ \\
\hline 4.73 & $\mathrm{CH}_{2}$ Protons at Methyl Group \\
\hline
\end{tabular}

In addition to sensor $\mathrm{L} 1$ with a concentration of $\mathrm{F}^{-}$ions ( $0-4$ equiv.), as shown in Figure 10, it was found that the NH signal disappeared upon the addition of $\mathrm{F}^{-}$ions at a 0.5 equivalent. It was assumed that the $\mathrm{NH}$ proton of the amide group disappeared from the molecule because of the strength basicity of $\mathrm{F}^{-}$ions. In addition, a new triplet peak was observed at $16.2 \mathrm{ppm}$, corresponding to the species of $\mathrm{HF}_{2}{ }^{-}$ions [38] upon the addition of 3-4 equivalents of $\mathrm{F}^{-}$ion, as shown in Figure 10E,F. The aromatic protons and methyl protons gradually moved upfield with the addition of $\mathrm{F}^{-}$ions from 0.5 equiv. to 4 equiv. 


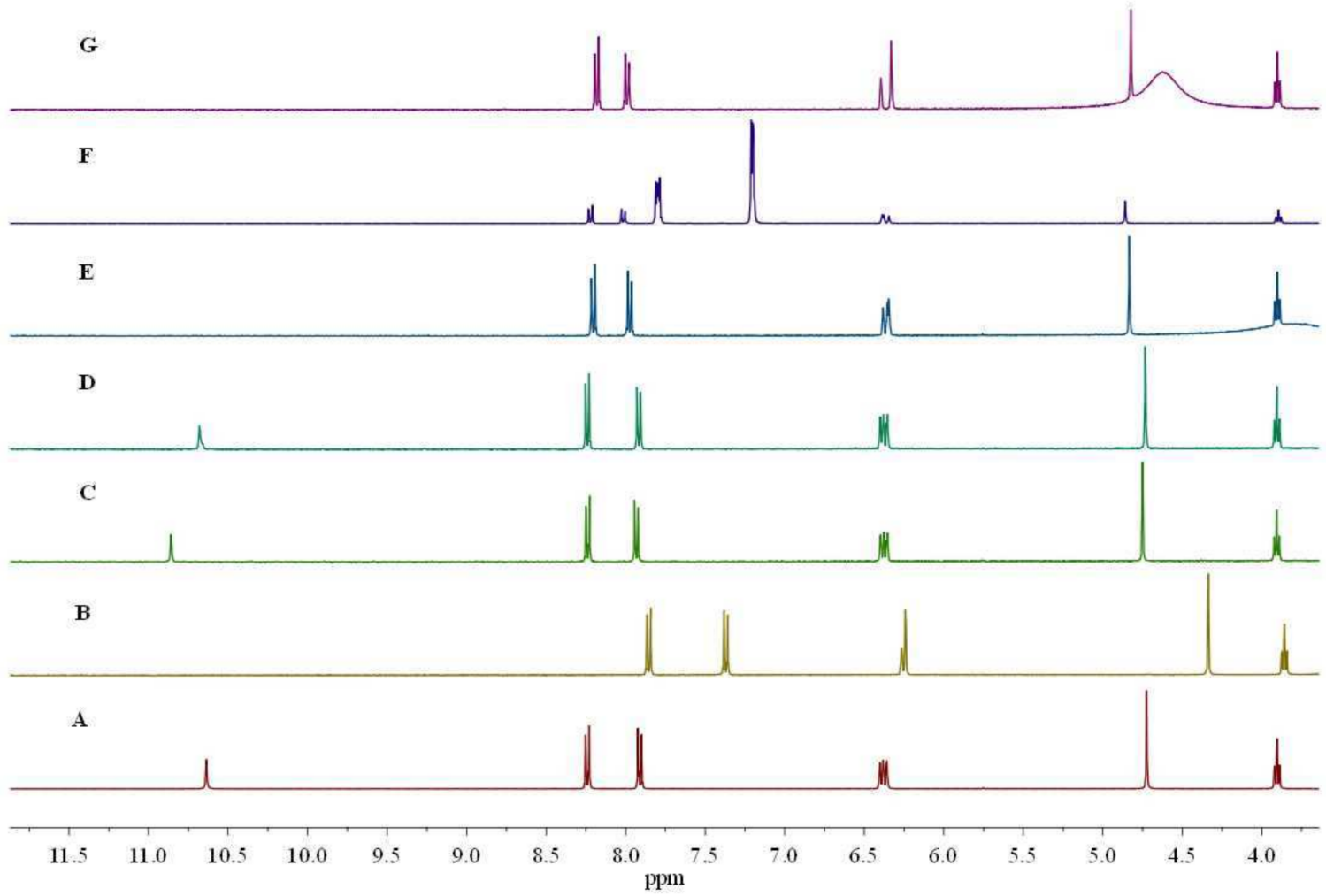

Figure 9. ${ }^{1} \mathrm{H}$ NMR spectra of sensor L1: (A) in DMSO- $d_{6}\left(5 \times 10^{-3} \mathrm{M}\right)$ upon addition of 4 equivalents of $(\mathbf{B}) \mathrm{F}^{-},(\mathbf{C}) \mathrm{Cl}^{-}$, (D) $\mathrm{Br}^{-}$, (E) $\mathrm{CH}_{3} \mathrm{COO}^{-}$, (F) $\mathrm{C}_{6} \mathrm{H}_{5} \mathrm{COO}^{-}$, and (G) $\mathrm{H}_{2} \mathrm{PO}_{4}^{-}$.

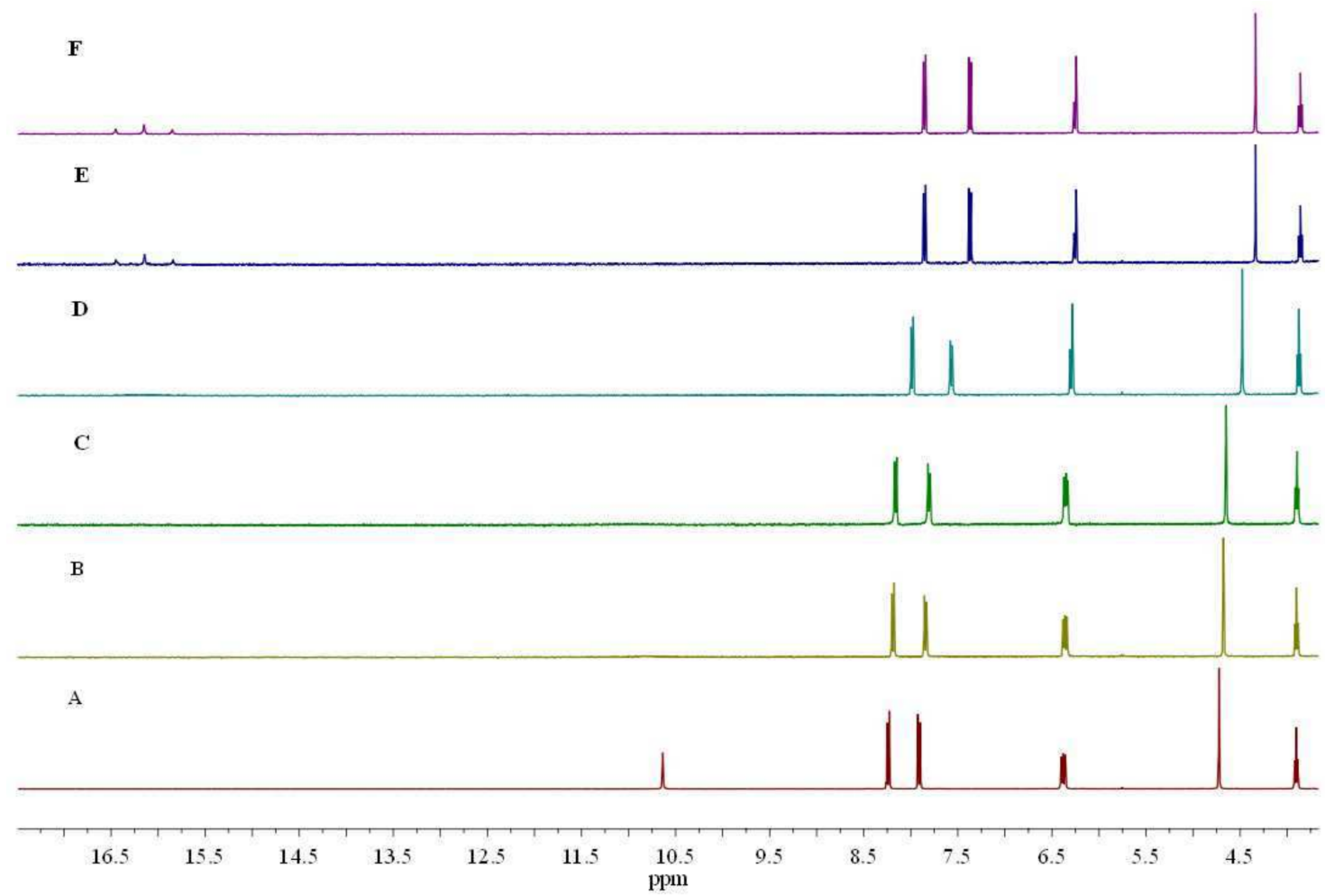

Figure 10. ${ }^{1} \mathrm{H}$ NMR titration spectra of sensor L1: (A) in DMSO- $d_{6}\left(5 \times 10^{-3} \mathrm{M}\right)$ upon addition of $(\mathbf{B}) \mathrm{F}^{-} 0.5$ equiv, $(\mathbf{C}) \mathrm{F}^{-}$ 1.0 equiv, (D) $\mathrm{F}^{-} 2.0$ equiv, (E) $\mathrm{F}^{-} 3.0$ equiv, and (F) $\mathrm{F}^{-} 4.0$ equiv. 
3.2.4. Determination of Association Constants $\left(K_{a}\right)$ and Detection Limit of Sensor L1 with $\mathrm{F}^{-}$Ions

Under a 1:1 binding complexation between sensor $\mathrm{L} 1$ and $\mathrm{F}^{-}$ions, the association constant $\left(\mathrm{K}_{\mathrm{a}}\right)$ was evaluated by the Benesi-Hildebrand equation as follows [40]:

$$
\frac{1}{\left(A-A_{0}\right)}=\left(\frac{1}{A_{\max }-A_{0}}\right)+\left(\frac{1}{K_{a}\left(A_{\max }-A_{0}\right)[G]^{n}}\right)
$$

The association constant of sensor $\mathrm{L} 1$ and $\mathrm{F}^{-}$ions was determined to be $1.92 \times 10^{3} \mathrm{M}^{-1}$. In the other anions, this cannot be calculated since their size and shape might not be suitable for the binding site, and interactions between sensor L1 and other anions are also much weaker. From the association constants, sensor L1 showed the highest affinity binding to fluoride ions.

The detection limit between sensor $\mathrm{L} 1$ and $\mathrm{F}^{-}$was calculated using a method present in the literature [41]. From the equation, the maximum and minimum absorbances were described as an absorbance at $430 \mathrm{~nm}$ of sensor $\mathrm{L} 1$ with 20 equivalents $\mathrm{F}^{-}$and an absorbance at $430 \mathrm{~nm}$ of sensor L1, respectively. (Figure 11) The detection limits of $\mathrm{F}^{-}$with sensor L1 was determined to be $0.77 \mathrm{mM}$.

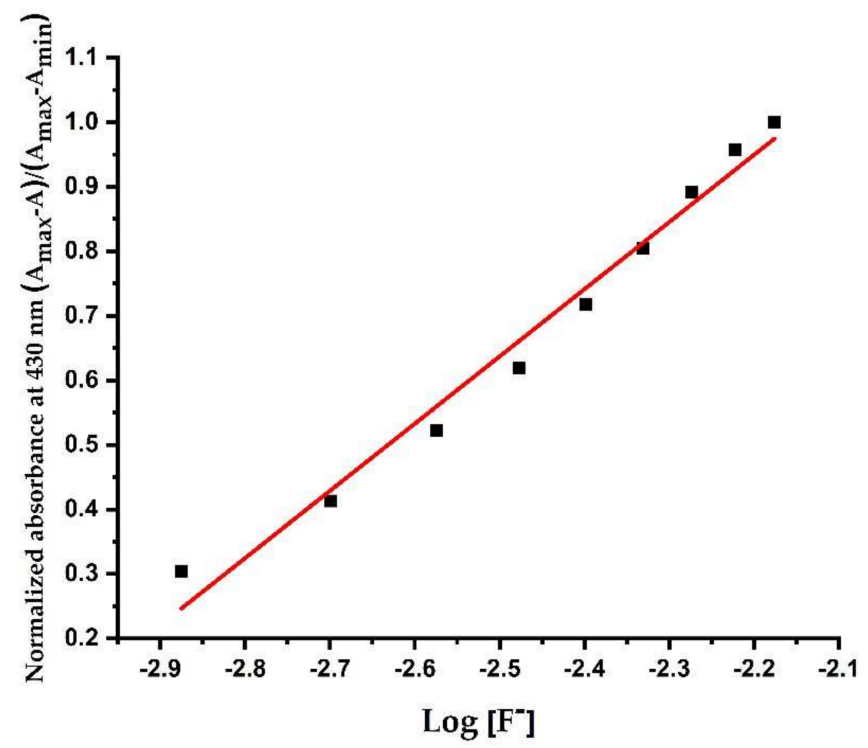

Figure 11. Normalized absorbance at $430 \mathrm{~nm}$ of sensor $\mathrm{L} 1$ with various concentrations of $^{-}{ }^{-}$ions.

\section{Conclusions}

In summary, sensor L1 was successfully designed and synthesized, including the product of crystals. The crystal structure revealed that the planes of the two functional groups (the alkyl chain and nitro benzene) were almost coplanar with the plane of toluene. The crystal packing was mainly supported by strong and weak hydrogen bonds, creating a one-dimensional array along the $b$-axis. From the ${ }^{1} \mathrm{H} \mathrm{NMR}$ results, the new $\mathrm{HF}_{2}{ }^{-}$species of L1 was found at $16.2 \mathrm{ppm}$ following the addition of fluoride ions. This result occurred via a deprotonation process. From UV-Vis titration in DMSO, it could be observed that sensor L1 displayed an isosbestic point at $378 \mathrm{~nm}$ and a new absorption band at $446 \mathrm{~nm}$, leading to a deprotonated form. Sensor L1 has a stronger interaction with fluoride ions than with other anions. Therefore, sensor L1 can be used as a fluoride sensor.

Supplementary Materials: The following are available online at https:/ /www.mdpi.com/article/10 .3390 / cryst11060671/s1, Figure S1: ${ }^{1}$ H NMR spectrum of sensor L1 in DMSO- $d_{6}$. 
Author Contributions: Conceptualization, methodology, funding acquisition and writing - original draft, B.W.; methodology, and writing, P.J.; writing, and methodology, T.D.; methodology, S.S. and K.C. All authors have read and agreed to the published version of the manuscript.

Funding: The authors thank the Kasetsart University Research and Development Institute and the Center of Excellence for Innovation in Chemistry (PERCH-CIC), the Ministry of Higher Education, Science, Research and Innovation.

Institutional Review Board Statement: Not applicable.

Informed Consent Statement: Not applicable.

Data Availability Statement: Not applicable.

Acknowledgments: The authors would like to thank the Department of Chemistry, Faculty of Science, Kasetsart University for supporting on certain facilities and equipment.

Conflicts of Interest: The authors declare no conflict of interest.

\section{References}

1. Hein, R.; Beer, P.D.; Davis, J.J. Electrochemical Anion Sensing: Supramolecular Approaches. Chem. Rev. 2020, 120, 1888-1935. [CrossRef] [PubMed]

2. Li, Z.; Rao, C.; Chen, L.; Fu, C.; Zhu, T.; Chen, X.; Liu, C. Addition of $\alpha$-Cyanomethylpyridine to Naphthalimide via Trifluoromethyl-Directed CH Functionalization: Cyanide Sensing in Aqueous Media. J. Org. Chem. 2019, 84, 7518-7522. [CrossRef]

3. Xiao, Y.; Chu, W.-K.; Ng, C.-O.; Cheng, S.-C.; Tse, M.-K.; Yiu, S.-M.; Ko, C.-C. Design and Synthesis of Luminescent Bis(isocyanoborato) Rhenate(I) Complexes as a Selective Sensor for Cyanide Anion. Organometallics 2020, 39, $2135-2141$. [CrossRef]

4. Guo, C.; Sun, S.; He, Q.; Lynch, V.M.; Sessler, J.L. Pyrene-Linked Formylated Bis(dipyrromethane): A Fluorescent Probe for Dihydrogen Phosphate. Org. Lett. 2018, 20, 5414-5417. [CrossRef]

5. Choi, S.-J.; Yoon, B.; Lin, S.; Swager, T.M. Functional Single-Walled Carbon Nanotubes for Anion Sensing. ACS Appl. Mater. Interfaces 2020, 12, 28375-28382. [CrossRef]

6. Jo, Y.; Chidalla, N.; Cho, N.-G. Bis-ureidoquinoline as a Selective Fluoride Anion Sensor through Hydrogen-Bond Interactions. J. Org. Chem. 2014, 79, 9418-9422. [CrossRef] [PubMed]

7. Qiu, Q.; Chen, H.; You, Z.; Feng, Y.; Wang, X.; Wang, Y.; Ying, Y. Shear Exfoliated Metal-Organic Framework Nanosheet-Enabled Flexible Sensor for Real-Time Monitoring of Superoxide Anion. ACS Appl. Mater. Interfaces 2020, 12, 5429-5436. [CrossRef] [PubMed]

8. Singh, H.; Devi, M.; Jena, N.; Iqbal, M.M.; Nailwal, Y.; De Sarkar, A.; Pal, S.K. Proton-Triggered Fluorescence Switching in Self-Exfoliated Ionic Covalent Organic Nanosheets for Applications in Selective Detection of Anions. ACS Appl. Mater. Interfaces 2020, 12, 13248-13255. [CrossRef]

9. Tretyakova, N.Y.; Lebedev, A.T.; Petrosyan, V.S. Degradetive Pathways for Aqueous Chlorination of Orcinol. Envion. Sci. Technol. 1994, 28, 606-613. [CrossRef] [PubMed]

10. Bao, X.; Zhou, Y.; Song, B. Recognition and Sensing Propeties a Quinazonyl Aminothiourea-Based Anion Receptor in NonAqueous and Aqueous $\mathrm{CH}_{3} \mathrm{CH}$-DMSO Medium. Sens. Actuators B Chem. 2012, 171-172, 550-555. [CrossRef]

11. Joo, T.Y.; Singh, N.; Lee, G.W.; Jang, D.O. Benzimidazole-Based Ratiometric Fluorescent Receptor for Selective Recognition of Acetate. Tetrahedron Lett. 2007, 48, 8846-8850. [CrossRef]

12. Kwon, J.Y.; Jang, Y.J.; Kim, S.K.; Lee, K.-H.; Kim, J.S.; Yoon, J. Unique Hydrogen Bonds between 9-Anthracenyl Hydrogen and Anions. J. Org. Chem. 2004, 69, 5155-5157. [CrossRef]

13. Li, Q.; Wu, Y.; Liu, Y.; Shangguan, L.; Shi, B.; Zhu, H. Rationally Designed Self-Immolative Rotaxane Sensor Based on Pillar[5]arene for Fluoride Sensing. Org. Lett. 2020, 22, 6662-6666. [CrossRef]

14. Kim, Y.-J.; Kwak, H.; Lee, S.J.; Lee, J.S.; Kwon, H.J.; Nam, S.H.; Lee, K.; Kim, C. Urea/Thiourea-Based Colorimetric Chemosensors for the Biologically Important Ions: Efficient and Simple Sensors. Tetrahedron 2006, 62, 9635-9640. [CrossRef]

15. Li, Y.; Li, J.; Lin, H.; Shao, J.; Cai, Z.-S.; Lin, H. A Novel Colorimetric Receptor Responding AcO- Anions based on an Azo Derivative in DMSO and DMSO/water Solution. J. Lumin 2010, 130, 466-472. [CrossRef]

16. Ling, L.; Hu, J.; Zhang, $\mathrm{H}$. Ferrocene Containing $\mathrm{N}$-tosylhydrazones as Optical and Electrochemical Sensors for $\mathrm{Hg}^{2+}, \mathrm{Cu}^{2+}$ and $\mathrm{F}^{-}$Ions. Tetrahedron 2019, 75, 2472-2481. [CrossRef]

17. Muwal, P.K.; Nayal, A.; Jaiswal, M.K.; Pandey, P.S. A Dipyrromethane based Receptor as a Dual Colorimetric Sensor for $\mathrm{F}^{-}$and $^{-}$ $\mathrm{Cu}^{2+}$ Ions. Tetrahedron Lett. 2018, 59, 29-32. [CrossRef]

18. Gautham, B.U.; Narayana, B.; Sarojini, B.K.; Manjunatha, J.G.; Suresh, N.K. Colorimetric 'Naked Eye' Sensor for Fluoride Ion based on Isatinhydrazones via Hydrogen Bond Formation: Design, Synthesis and Characterization ascertained by Nuclear Magnetic Resonance, Ultraviolet-Visible, Computational and Electrochemical studies. Inorg. Chem. Commun. 2020, 121, 108216. [CrossRef] 
19. Chen, W.; Guo, C.; He, Q.; Chi, X.; Lynch, V.M.; Zhang, Z.; Su, J.; Tian, H.; Sessler, J.L. Molecular Cursor Caliper: A Fluorescent Sensor for Dicarboxylate Dianions. J. Am. Chem. Soc. 2019, 141, 14798-14806. [CrossRef] [PubMed]

20. Reena, V.; Suganya, S.; Velmathi, S. Synthesis and anion binding studies of azo-Schiff bases: Selective colorimetric fluoride and acetate ion sensors. J. Fluor. Chem. 2013, 153, 89-95. [CrossRef]

21. Yu, X.-F.; Xiao, B.; Cheng, J.; Liu, Z.-B.; Yang, X.; Li, Q. Theoretical Design of Near-Infrared Fluorescent Sensor for F Anion Detection Based on 10-Hydroxybenzo[h]quinoline Backbone. ACS Omega 2019, 4, 10516-10523. [CrossRef]

22. Lv, T.-T.; Ju, C.-G.; Liu, B.-N.; Ren, X.-H.; Shan, G.-S.; Jia, T.-Z. Determination of Orcinol Glucoside by LC-MS in Curculigo Orchiioides and Its Application to a Pharmacokinetic Study. Rev. Bras. Farmacogn. 2019, 29, 744-748. [CrossRef]

23. Rautenberg, M.; Bhattacharya, B.; Akhmetova, I.; Emmerling, F. Mechanochemical and Solution Syntheses of Two Novel Cocrystals of Orcinol with Two N,N'-Dipyridines: Structural Diversity with Varying Ligand Flexibility. J. Mol. Struct. 2020, 1217, 128303. [CrossRef]

24. Kanekar, Y.; Basha, K.; Duche, S.; Gupte, R.; Kapat, A. Regioselective Synthesis of Phenanthrenes and Evaluation of their Anti-Oxidant based Anti-Inflammatory Potential. Eur. J. Med. Chem. 2013, 67, 454-463. [CrossRef] [PubMed]

25. Krishna, B.R.; Thummuri, D.; Naidu, V.G.M.; Ramakrishna, S.; Mallavadhani, U.V. Synthesis of Some Novel Orcinol based Coumarin Triazole Hybrids with Capabilities to Inhibit RANKL-Induced Osteoclastogenesis through NF- $\mathrm{B}$ Signaling Pathway. Bioorg. Chem. 2018, 78, 94-102. [CrossRef]

26. Pham, P.J.; Hernandez, R.; French, W.T.; Estill, B.G.; Mondala, A.H. A Spectrophotometric Method for Quantitative Determination of Xylose in Fermentation Medium. Biomass Bioenergy 2011, 35, 2814-2821. [CrossRef]

27. Monde, K.; Satoh, H.; Nakamura, M.; Tamura, M.; Takasygi, M. Organochloride Compounds from a Terrestrial Higher Plant: Structure and Origin of Chlorinated Orcinol Derivatives from Diseased Bulbs of Lilium Maximowiczii. J. Nat. Prod. 1998, 61, 913-921. [CrossRef]

28. Mukherjee, A.; Grobelny, P.; Thakur, T.S.; Desiraju, G.R. Polymorphs, Pseudopolymorphs, and Co-Crystals of Orcinol: Exploring the Structural Landscape with High Throughput Crystallography. Cryst. Growth Des. 2011, 11, 2637-2653. [CrossRef]

29. Singh, A.; Nishith, U.; Trivedi, D.R. Spectroscopic Studies of Colorimetric Receptors for Detection of Biologically Important Inorganic $\mathrm{F}-$, AcO- and H2PO4- Anions in Organo-Aqueous Medium: Real-Life Application. Inorg. Chem. Commun. 2020, 115, 107874. [CrossRef]

30. Erdemir, S.; Kocyigit, O.; Alici, O.; Malkondu, S. 'Naked-Eye' Detection of $\mathrm{F}^{-}$Ions by Two Novel Colorimetric Receptors. Tetrahedron Lett. 2013, 54, 613-617. [CrossRef]

31. Bruker, S. APEX3, SAINT and SADABS; Bruker AXS Inc.: Madison, WI, USA, 2016.

32. Spek, A.L. PLATON SQUEEZE: A Tool for the Calculation of the Disordered Solvent Contribution to the Calculated Structure Factors. Acta Cryst. 2015, C71, 9-18.

33. Sheldrick, G.M. SHELXT-Integrated Space-Group and Crystal-Structure Determination. Acta Cryst. 2015, A71, 3-8. [CrossRef] [PubMed]

34. Sheldrick, G.M. Crystal Structure Refinement with SHELXL. Acta Cryst. 2015, C71, 3-8.

35. Macrae, C.F.; Bruno, I.J.; Chisholm, J.A.; Edgington, P.R.; McCabe, P.; Pidcock, E.; Rodriguez-Monge, L.; Taylor, R.J.; van de Streek, J.; Wood, P. Mercury CSD 2.0-New Features for the Visualization and Investigation of Crystal Structures. J. Appl. Crystallogr. 2008, 41, 466-470. [CrossRef]

36. Wen, Y.-H.; Li, X.-M.; Xu, L.-L.; Tang, X.-F.; Zhang, S.-S. 2-Chloro-N-(4-nitrophenyl)acetamide. Acta Cryst. 2006, E62, o4427-o4428. [CrossRef]

37. Deka, B.; Sarma, R.J. Concentration Dependent Colour Switching of Tryptophan-Derived 3,5-dinitrobenzamide Ligands in the Presence of Fluoride Anions. Sens. Actuators B Chem. 2014, 197, 321-325. [CrossRef]

38. Okudan, A.; Erdemir, S.; Kocyigit, O. 'Naked-Eye' Detection of Fluoride and Acetate Anions by Using Simple and Efficient Urea and Thiourea based Colorimetric Sensors. J. Mol. Struct. 2013, 1048, 392-398. [CrossRef]

39. Peng, X.; Wu, Y.; Fan, J.; Tian, M.; Han, K. Colorimetric and Ratiometric Fluorescence Sensing of Fluoride: Tuning Selectivity in Proton Transfer. J. Org. Chem. 2005, 70, 10524-10531. [CrossRef]

40. Zou, L.; Yan, B.; Pan, D.; Tan, Z.; Bao, X. A Colorimetric and Absorption Ratiometric Anion Sensor Based on Indole \& Hydrazide Binding Units. Spectrochim. Acta Part A Mol. Biomol. Spectrosc. 2015, 148, 78-84.

41. Wang, C.; Li, G.; Zhang, Q. A Novel Heteroacene, 2-(2,3,4,5-tetrafluorophenyl)-1H-imidazo[4,5-b]phenazine as a Multi-Response Sensor for $\mathrm{F}^{-}$Detection. Tetrahedron Lett. 2013, 54, 2633-2636. [CrossRef] 